\title{
Intestinal Lymphangiectasia: a Protein-Losing Enteropathy with Hypogammaglobulinemia, Lymphocytopenia and Impaired Homograft Rejection*
}

\author{
W. Strober, $\ddagger$ R. D. Woch ner, P. P. Carbone, and T. A. Waldmann \\ (From the Metabolism Branch and the Medicine Branch, National Cancer Institute, National \\ Institutes of Health, Bethesda, Maryland)
}

\begin{abstract}
Intestinal lymphangiectasia is a disease characterized by dilated intestinal lymphatics, protein-losing enteropathy, hypoalbuminemia, and edema. The immunologic status of 18 patients with intestinal lymphangiectasia was studied. Concentrations of $\operatorname{IgG}, \operatorname{IgA}$, and $\operatorname{IgM}$ were measured by immune precipitation and metabolism of these three immunoglobulins was studied using purified radioiodinated proteins. The serum concentration and total body pool of each immunoglobin were greatly reduced. The fraction of the intravascular protein pool catabolized per day was increased to $34 \%$ for IgG, $59 \%$ for $\operatorname{IgA}$, and $66 \%$ for IgM ; these are in contrast with control values of $7 \%, 28 \%$, and $17 \%$, respectively. Synthetic rates of the immunoglobulins were normal or slightly increased.

Primary circulating antibody response was tested in five patients with Vi and tularemia antigens. Titers elicited in patients with the $\mathrm{Vi}$ antigen were significantly lower than those seen in a control group, whereas no difference was seen between patient and control responses to the tularemia antigen.

Lymphocytopenia was noted in patients with intestinal lymphangiectasia. The mean circulating lymphocyte count was $710 \pm 340 / \mathrm{mm}^{3}$ in contrast to $2500 \pm 600 / \mathrm{mm}^{3}$ in controls. Cellular hypersensitivity was studied with skin tests and skin grafts. $91 \%$ of normal individuals reacted to at least one of the four skin test antigens: purified protein derivative, mumps, Trichophyton, and Candida albicans; in contrast, only $17 \%$ of patients with intestinal lymphangiectasia had a positive reaction. Each of three patients tested with dinitrochlorobenzene had a negative reaction. Finally, all four patients who received skin homografts have retained these grafts for at least 12 months. The immunological disorders in patients with intestinal lymphangiectasia appear to result from loss of immunoglobulins and lymphocytes into the gastrointestinal tract secondary to disorders of lymphatic channels. Lymphocyte depletion then leads to skin anergy and impaired homograft rejection.
\end{abstract}

\section{Introduction}

Immunologic deficiency may take a variety of forms. It may be manifest as a defect in the synthesis of one or more serum immunoglobulins as

* Received for publication 17 March 1967 and in revised form 10 May 1967.

Presented in part at the 58th Annual Meeting of the American Society for Clinical Investigation, Atlantic City, N. J., 1 May 1966; published in abstract form in J. Clin. Invest. 1966, 45 : 1077. in the complex group of hypogammaglobulinemias, in which case circulating antibody response to antigenic challenge is greatly reduced (1). Alternatively, it may be seen as an abnormality in cellular or delayed hypersensitivity as in Hodgkin's disease; in this instance, circulating antibody response is intact, but the ability to manifest de-

$\ddagger$ Address requests for reprints to Dr. Warren Strober, Metabolism Branch, National Cancer Institute, National Institutes of Health, Bethesda, Md. 20014. 
layed skin reactions to certain antigens and to reject homografts (allografts) is impaired $(2,3)$.

We now characterize an immune deficiency state associated with the disease, intestinal lymphangiectasia. Intestinal lymphangiectasia is a chronic disorder of lymphatics associated with severe protein-losing gastroenteropathy (4). Patients with this disorder have marked hypoproteinemia and severe, often asymmetrical, edema. Gastrointestinal symptoms are usually mild. Malabsorption of fat may occur, but is usually not severe. The hallmark morphological lesion of this disease is dilated lymphatic channels of the small bowel (Fig. 1) ; peripheral lymphatic abnormalities may also be demonstrated by lymphangiography. These structural lymphatic abnormalities

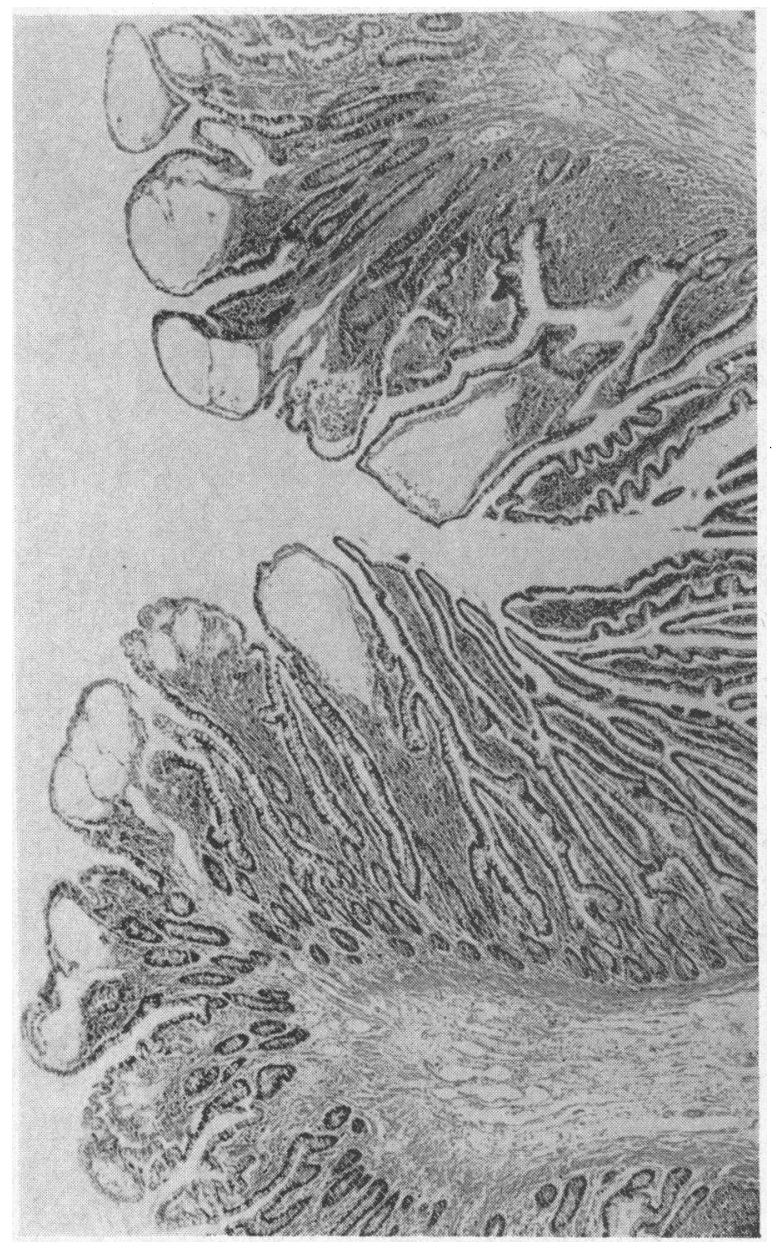

Fig. 1. Small intestinal biopsy from a patient WITH INTESTINAL LYMPHANGIECTASIA. Dilated lymphatics are seen in the tips of villi and in the lamina propria. occur as congenital malformations or as acquired defects.

In this study, patients with intestinal lymphangiectasia were found to have low serum immunoglobulin levels secondary to increased fractional catabolic rates for these proteins. The increased catabolism was attributable to excessive loss of serum proteins into the gastrointestinal lumen. A considerable antibody response was observed after antigenic challenge, but this response was slightly less than that observed in normal individuals. A very severe peripheral lymphocytopenia was regularly seen and this was associated with greatly decreased skin reactivity to certain antigens. Most striking was the fact that these patients accepted skin grafts from unrelated donors.

\section{Methods}

\section{Patients}

Data obtained from 18 patients with intestinal lymphangiectasia are included in Table $\mathrm{I}$. The subjects ranged in age from 4 months to $79 \mathrm{yr}$; the average duration of disease was $11 \mathrm{yr}$. Each patient was shown to have dilated subepithelial lymphatic channels by peroral small bowel biopsy or lapartomy. Edema and hypoproteinemia were present in each case. The mean total serum protein concentration was $3.8 \mathrm{~g} / 100 \mathrm{ml}$ (range: $2.5-5.5 \mathrm{~g}$ / $100 \mathrm{ml}$ ) and the mean serum albumin concentration was $1.8 \mathrm{~g} / 100 \mathrm{ml}$ (range: $0.8-3.4 \mathrm{~g} / 100 \mathrm{ml}$ ). Each patient had a markedly shortened albumin survival and a normal albumin synthetic rate as demonstrated by iodinated albumin turnover studies. Each of the patients had either abnormally high 4 day polyvinylpyrrolidone- ${ }^{131} \mathrm{I}$ gastrointestinal excretion (mean of $9.3 \%$ of injected dose vs. $<1.5 \%$ of injected dose in controls) or high 4 day albumin ${ }^{51} \mathrm{Cr}$ excretion (mean of $12.8 \%$ of injected dose vs. $<0.75 \%$ of injected dose in controls). These findings indicated that the hypoproteinemia and shortened plasma protein survival were due to excessive gastroeintestinal protein loss $(5,6)$.

The patients were clinically stable during the periods of study; they were free of infection, were afebrile, and maintained constant weight. Drug therapy was limited to diuretics. Tests of liver and renal function were normal and the patients did not have proteinuria. There were no concomitant illnesses except for pulmonary emphysema in patient $\mathrm{J}$. T., and diabetes mellitus in patient I. S.

\section{Serum immunoglobulin quantitation}

Serum immunoglobulin concentrations were determined by radial immunodiffusion $(7,8)$. Samples were allowed to diffuse from wells made in agar impregnated with specific antiserum. ${ }^{1}$ The diameter of the precipitin ring

1 Hyland Laboratories, Los Angeles, Calif. 
TABLE I

Data from 18 patients with intestinal lymphangiectasia

\begin{tabular}{|c|c|c|c|c|c|c|c|c|}
\hline \multirow[t]{2}{*}{ Patient } & \multirow[t]{2}{*}{ Sex } & Age & $\begin{array}{l}\text { Duration } \\
\text { of disease }\end{array}$ & Major symptoms & \multicolumn{2}{|c|}{$\begin{array}{c}\begin{array}{c}\text { Evidence of } \\
\text { protein-losing enteropathy }\end{array} \\
\text { Albumin }={ }^{61} \mathrm{Cr} \text { PVP }={ }^{121} \mathrm{I}\end{array}$} & $\begin{array}{l}\text { Total } \\
\text { protein }\end{array}$ & Albumin \\
\hline & & $y r$ & $y r$ & & $\begin{array}{l}\text { \%inj } \\
\text { excreted }\end{array}$ & $\begin{array}{l}\text { ose } \\
4 \text { days }\end{array}$ & $\mathrm{g} / 100 \mathrm{ml}$ & $\mathrm{g} / 100 \mathrm{ml}$ \\
\hline J. B. & M & \multicolumn{2}{|c|}{5 months 4 months } & Edema; diarrhea & & 34.2 & 2.5 & 0.9 \\
\hline J. M. & $\mathbf{M}$ & 7 & 6 & Edema; chylous ascites & & 4.4 & 3.4 & 0.9 \\
\hline L. H. & $\mathrm{F}$ & 29 & $20+$ & $\begin{array}{l}\text { Mild edema; minor } \\
\text { infections }\end{array}$ & 8.8 & 2.9 & 4.8 & 2.1 \\
\hline H. M. & M & 7 & 2 & $\begin{array}{l}\text { Edema; growth } \\
\text { retardation }\end{array}$ & & 3.8 & 3.3 & 1.6 \\
\hline D. H. & $\mathrm{F}$ & 16 & $14+$ & Edema; ascites & 11.9 & 10.5 & 3.4 & 1.4 \\
\hline R. D. & $\mathrm{F}$ & 23 & 8 & Edema & & 4.2 & 4.0 & 2.0 \\
\hline R. B. & M & 18 & 18 & Edema & 6.4 & & 5.5 & 3.4 \\
\hline B. C. & $\mathrm{F}$ & 28 & 24 & $\begin{array}{l}\text { Massive peripheral } \\
\text { edema }\end{array}$ & 5.1 & 13.9 & 4.1 & 2.5 \\
\hline N. W. & $\mathrm{F}$ & 35 & 5 & Edema; diarrhea & & 6.0 & 3.0 & 1.4 \\
\hline J. T. & M & 47 & 22 & Edema; chronic fatigue & 19.6 & 5.8 & 3.5 & 1.6 \\
\hline D. S. & $\mathrm{F}$ & 6 & 6 & Edema; ascites & 29.0 & & 4.8 & 2.5 \\
\hline S. W. & $\mathbf{M}$ & 9 & 4 & Edema & & 9.8 & 3.8 & 1.7 \\
\hline D. L. & $\mathrm{F}$ & 7 & 7 & $\begin{array}{l}\text { Edema; chylothorax } \\
\text { and chylous ascites }\end{array}$ & & 14.9 & 3.6 & 0.8 \\
\hline E. B. & $\mathrm{F}$ & 45 & 20 & $\begin{array}{l}\text { Edema; frequent } \\
\text { minor infections }\end{array}$ & 1.5 & 2.4 & 3.9 & 1.9 \\
\hline G. L. & $\mathrm{F}$ & 43 & 15 & Edema; diarrhea & 12.3 & 10.0 & 3.0 & 2.1 \\
\hline N. B. & M & 30 & 12 & Edema; abdominal pain & 14.7 & 10.7 & 3.5 & 1.5 \\
\hline R. S. & M & 26 & 5 & Edema; chylothorax & & 5.7 & 3.0 & 1.1 \\
\hline I. S. & $\mathrm{F}$ & 79 & 15 & Edema; chylous ascites & 18.6 & & 4.5 & 2.1 \\
\hline $\begin{array}{l}\text { Mean } \\
\text { Norma }\end{array}$ & & & 11 & & $\begin{array}{l}12.8 \\
<0.75\end{array}$ & $\begin{array}{r}9.3 \\
<1.5\end{array}$ & $\begin{array}{l}3.8 \\
6.0-8.0\end{array}$ & $\begin{array}{l}1.8 \\
3.1-4.5\end{array}$ \\
\hline
\end{tabular}

PVP, polyvinylpyrrolidone.

obtained was compared with that of dilutions of a reference standard.2 Normal values were established with a panel of 50 control sera using identical techniques.

\section{Purification of immunoglobulins}

(a) $I g G$. IgG was prepared from normal sera by DEAE cellulose chromatography by modification of a technique previously described (9). Sterile serum samples obtained immediately before fractionation were dialyzed against $0.005 \mathrm{M}$ potassium phosphate buffer, $\mathrm{pH}$ 8.0. $2-3 \mathrm{ml}$ of dialyzed serum was applied to a $1 \times 25$ $\mathrm{cm}$ column containing DEAE cellulose equilibrated with the phosphate buffer. The first peak eluted from this column with this buffer contained only IgG as shown with $\mathrm{H}$ chain-specific antisera.

(b) $\operatorname{Ig} M$. IgM was obtained by block electrophoresis followed by gel filtration, as previously described (10). Serum from a normal donor was electrophoresed for $18 \mathrm{hr}$ in sodium barbital buffer, $\mathrm{pH} 8.6$, with a mix-

2 Provided by Dr. John L. Fahey. ture of polyvinylchloride ${ }^{3}$ and polyvinylchloride-polyvinylacetate copolymer ${ }^{4}$ as a supporting media. The $\boldsymbol{\gamma}$-globulin region was eluted, concentrated, and dialyzed against $1.0 \mathrm{M}$ sodium chloride, $0.1 \mathrm{M}$ Tris buffer at $\mathrm{pH} 8$. It was then applied to a Sephadex G-200 5 column equilibrated with the same buffer. The ascending limb of the first protein peak obtained in the effluent was concentrated by ultrafiltration and found to contain only IgM by Ouchterlony analysis.

(c) $\operatorname{IgA}$. IgA was prepared by block electrophoresis of serum from a patient with markedly elevated IgA. This elevation has been observed for $7 \mathrm{yr}$ without evidence of myeloma or other neoplastic disease. After electrophoresis, sections of the block were eluted with saline and examined for the presence of $\mathrm{IgA}$. One of two ${ }^{3}$ Geon Vinyl Resins, B. F. Goodrich Chemical Co., Niagara Falls, N. Y.

\& Pevikon, Superfosfat, Fabrika, Aktiebolog, Stockholm, Sweden.

${ }^{5}$ Sephadex, Pharmacia Fine Chemicals, Inc., New York, N. Y. 
preparations was ultimately used for turnover study. Each of these preparations were analyzed by radioimmunoelectrophoresis and with radial immunodiffusion quantitation: preparation A contained $90 \% \operatorname{IgA}$ and $10 \%$ transferrin; preparation $\mathrm{B}$ contained $85 \% \operatorname{IgA}$ and $15 \%$ IgG.

\section{Iodination of purified proteins.}

Iodination of each of the above preparations was performed with either ${ }^{131} \mathrm{I}$ or ${ }^{125} \mathrm{I}$ by the iodine monochloride technique of McFarlane (11). All preparations were calculated to have an average of less than one atom of iodine per molecule of protein in the final product. The final product contained less than $1 \%$ nonprecipitable radioactivity. Normal human albumin was added to each preparation to prevent damage to the protein by irradiation.

\section{Protocol for turnover studies}

Each patient was admitted to the National Cancer Institute during the study period. 10 drops of Lugol's solution were administered 3 times daily throughout the study period to prevent thyroidal uptake of the released isotope. Serum immunoglobulin concentrations were obtained at intervals throughout the study period to verify that each patient was in a steady state. Turnover studies of the protein preparations were done either simultaneously or sequentially. From 10 to $50 \mu \mathrm{c}$ of the iodinated proteins was administered intravenously from a calibrated syringe, and serum samples were obtained $10 \mathrm{~min}$ after administration, and daily thereafter. Stool and urine specimens were collected in 24-hr lots. Serum and urine samples were counted with appropriate standards to within $\pm 3 \%$ counting error in an automatic gamma-ray well-type scintillation counter with a thallium-activated sodium iodide crystal. When two isotopes were studied simultaneously, they were differentiated with a pulse height analyzer.

\section{Calculation of the metabolic data}

The turnovers of the iodinated proteins were analyzed according to a modification of the methods of Berson, Yalow, Schreiber, and Post (12), and Pearson, Veall, and Vetter (13). The calculations are summarized as follows: plasma volume $(\mathrm{ml} / \mathrm{kg})=$ radioactivity administered/(radioactivity per milliliter plasma at $10 \mathrm{~min} X$ body weight) ; radioactivity retained in the body $=$ radioactivity administered - cumulative excreted radioactivity.

Time plots of the plasma radioactivity and the radioactivity retained in the body were constructed on semilogarithmic graph paper, and the survival half-times of the labeled proteins were determined graphically. The fraction of the body protein remaining in the intravascular space $=($ plasma volume $\times$ plasma radioactivity per milliliter)/radioactivity retained in the body; this fraction was determined after equilibration of the labeled protein among the body compartments. Total circulating protein $=$ plasma volume $\times$ plasma concentration of the protein. Total exchangeable pool of the protein = total circulating protein/fraction of the protein in the intravascular space. Fraction of the circulating protein catabolized per day = radioactivity excreted in each $24-\mathrm{hr}$ period/mean circulating radioactivity during the same period. This fraction was determined for each day, and the mean value for days $3-15$ was taken as the fractional catabolic rate. Absolute catabolic rates (turnover rates) $=$ the total circulating protein $\times$ fraction of circulating protein catabolized per day.

Since the concentration of each of the plasma proteins studied remained constant throughout the period of study, the patients were assumed to be in a steady state as far as protein metabolism was concerned, and the synthetic rates for the proteins were considered to be equal to the turnover rates.

\section{Lymphocyte levels}

Blood lymphocyte levels were determined for 18 patients with intestinal lymphangiectasia and 50 young adult controls. Lymphocyte counts were computed from the products of the total venous white blood counts and differential counts. Each reported count represents the mean of from 2 to 10 determinations.

\section{Antibody stimulation studies}

The ability to produce antibodies in response to specific antigens was determined in five patients with intestinal lymphangiectasia and 14 normal control subjects (mean age 25). The antigens used were (a) $\mathrm{Vi}$ antigen ( Vi), a polysaccharide isolated from $5396 / 38$ strain of $E$. coli $(14,15)$, and $(b)$ Foshay tularemia vaccine, the cell wall of Pasteurella tularensis (16). These antigens were chosen since prior exposure was unlikely, and measured antibody responses were therefore primary in nature. $100 \mu \mathrm{g}$ of $\mathrm{Vi}$ and $1 \mathrm{ml}$ of Foshay vaccine were given intramuscularly to each patient. Antibody titers were determined on specimens drawn at weekly intervals for $4 \mathrm{wk}$ after injections. Titers were done concomitantly on all samples using antigen-coated red cells in a hemagglutination titration method $(17,18)$. The highest dilution giving a $2+$ agglutination reaction was taken as the end point of the assay.

\section{Skin tests}

Purified protein derivative (PPD), ${ }^{6}$ Trichophyton, 7 Candida albicans, ${ }^{7}$ and mumps ${ }^{8}$ antigens were obtained from commercial sources and injected intradermally into the forearm of both patients with intestinal lymphangiectasia and normal volunteer control subjects. Reactions were considered positive if at least $1 \mathrm{~cm}$ of induration occurred at the test site at $48 \mathrm{hr}$.

Dinitrochlorobenzene (DNCB) skin test (19) sensitization was performed by applying $2000 \mu \mathrm{g}$ of DNCB in acetone on a midforearm site; $100 \mu \mathrm{g}$ DNCB was applied concomitantly to serve as a presensitizing dose control. The initial $2000 \mu \mathrm{g}$ dose caused a vesicant reaction in all

\footnotetext{
${ }^{6}$ Parke, Davis \& Co., Detroit, Mich.

${ }^{7}$ Hollister-Stier Laboratories, Inc., Yeadon, $\mathrm{Pa}$.

8 Eli Lilly \& Co., Indianapolis, Ind.
} 
subjects. 2 wk after sensitization, a $100 \mu \mathrm{g}$ challenge dose was applied. A positive reaction was said to occur if at least $1 \mathrm{~cm}$ of induration was present $48 \mathrm{hr}$ after application and was significantly greater than the initial $100 \mu \mathrm{g}$ dose reaction.

\section{Skin grafts}

The skin grafts were obtained from nonrelated, healthy donors by taking an $8 \mathrm{~mm}$ punch biopsy from the interscapular area. No information is available as to the white cell grouping of donors or recipients. The skin was then placed on empty punch biopsy sites of the recipient, usually on the upper medial arm region. The grafts were held in place with bandages and carefully observed over a prolonged period of time. Photographs of the grafts were taken at appropriate intervals.

\section{Results}

Immunoglobulin levels. Serum concentrations of the three major classes of immunoglobulins of 12 patients with intestinal lymphangiectasia are shown in the scattergrams of Fig. 2. Mean IgG levels were $4.5 \pm 2.1 \mathrm{mg} / \mathrm{ml}$ compared to $12.1 \pm$ $2.7 \mathrm{mg} / \mathrm{ml}$ in controls; mean IgA levels were at
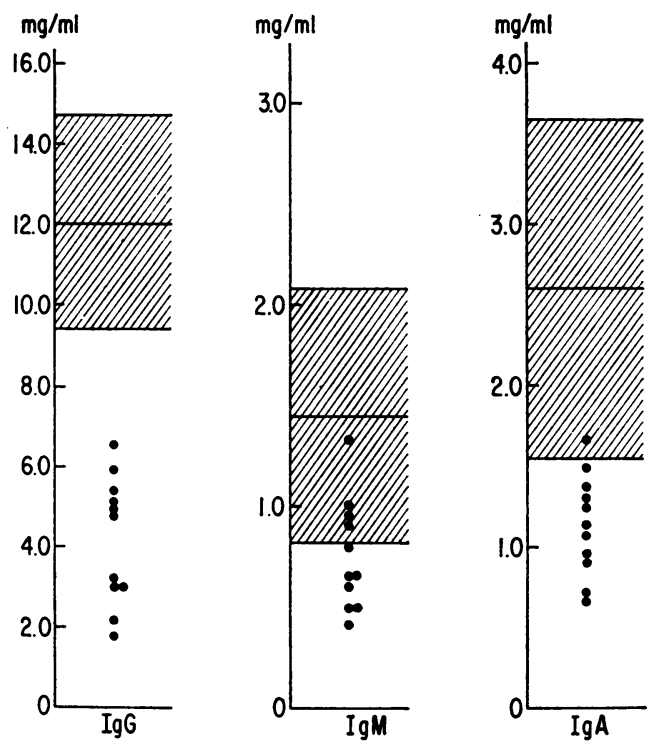

Fig. 2. Serum immunoglobulin concentrations in PATIENTS WITH INTESTINAL LYMPhANGIECTASIA. The normal mean of 50 control patients is indicated by the central horizontal line and one standard deviation about the mean by the cross-hatched areas.
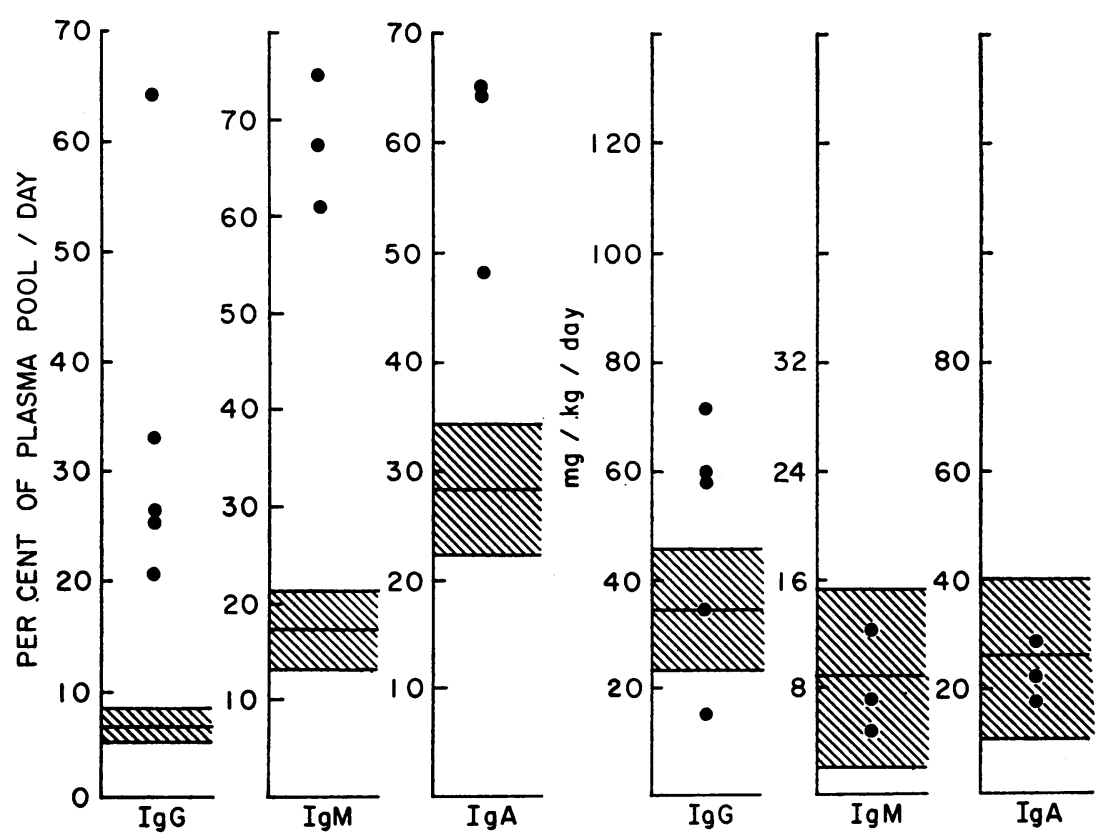

Fig. 3. Immunoglobulin metabolism in patients With intestinal lymphAngiectasia. Fractional catabolic rates are plotted in the three left panels. Synthetic rates are plotted in the three right panels. The means of control groups are represented by the central horizontal lines and one standard deviation about the mean by the cross-hatched areas. The fractional catabolic rates are elevated and synthetic rates are normal or slightly elevated in patients with intestinal lymphangiectasia. 
TABLE II

IgG Metabolism in intestinal lymphangiectasia

\begin{tabular}{|c|c|c|c|c|c|c|c|c|}
\hline Patient & $\begin{array}{c}\text { Age, } \\
\text { sex }\end{array}$ & $\begin{array}{c}\text { Serum } \\
\text { level }\end{array}$ & $\begin{array}{c}\text { Total } \\
\text { circulating } \\
\text { IgG }\end{array}$ & $\begin{array}{c}\text { Total } \\
\text { exchangeable } \\
\text { IgG }\end{array}$ & $\begin{array}{l}\text { Intra- } \\
\text { vascular }\end{array}$ & $\underset{t_{l}}{\text { Survival }}$ & $\begin{array}{l}\text { Fractional } \\
\text { catabolic } \\
\text { rate }\end{array}$ & $\begin{array}{l}\text { Synthetic } \\
\text { rate }\end{array}$ \\
\hline & & $m g / m l$ & $m g / k g$ & $m g / k g$ & $\%$ & days & $\%$ IV pool/day & $m g / k g$ per day \\
\hline L. H. & $28 \mathrm{~F}$ & 1.9 & 73 & 160 & 45.6 & 7.1 & 20.6 & 15 \\
\hline N. B. & $40 \mathrm{M}$ & 5.0 & 180 & 400 & 45.0 & 4.7 & 33.0 & 59 \\
\hline J. T. & $44 \mathrm{M}$ & 4.0 & 110 & 400 & 27.5 & 3.9 & 64.5 & 71 \\
\hline E. B. & $46 \mathrm{M}$ & 3.0 & 130 & 380 & 34.2 & 7.8 & 26.0 & 34 \\
\hline I. S. & $70 \mathrm{M}$ & 6.5 & 230 & 740 & 31.1 & 8.8 & 25.4 & 58 \\
\hline \multicolumn{2}{|c|}{$\begin{array}{l}\text { Patient Mean } \\
\text { Controls (23) }\end{array}$} & $\begin{array}{r}4.1 \pm 1.7 \\
12.1 \pm 2.6\end{array}$ & $\begin{array}{l}145 \pm 62 \\
494 \pm 116\end{array}$ & $\begin{array}{r}416 \pm 207 \\
1090 \pm 263\end{array}$ & $\begin{array}{l}36.7 \pm 8.2 \\
45.3 \pm 6.1\end{array}$ & $\begin{array}{r}6.5 \pm 2.1 \\
22.9 \pm 4.0\end{array}$ & $\begin{array}{r}33.9 \pm 17.7 \\
6.7 \pm 1.5\end{array}$ & $\begin{array}{l}47 \pm 22 \\
34 \pm 11\end{array}$ \\
\hline
\end{tabular}

$1.15 \pm 0.32 \mathrm{mg} / \mathrm{ml}$ compared to $2.61 \pm 1.07 \mathrm{mg} /$ $\mathrm{ml}$ in controls; and mean IgM levels were $0.76 \pm$ $0.26 \mathrm{mg} / \mathrm{ml}$ compared to $1.45 \pm 0.68 \mathrm{mg} / \mathrm{ml}$ in control subjects. These reductions, while most marked in the IgG group, are statistically significant for all the major immunoglobulin categories $(P=<0.001$ using Student's $t$ test $)$.

Immunoglobulin metabolism. To determine the cause of the reduced serum immunoglobulin concentrations, we performed metabolic turnover studies using purified radioiodinated proteins. The turnover of intravenously adninistered, radioiodinated IgG was studied in five patients (Fig. 3, Table II). Total circulating IgG and total exchangeable IgG were greatly reduced: 145 and $416 \mathrm{mg} / \mathrm{kg}$ compared to 494 and $1090 \mathrm{mg} / \mathrm{kg}$ in controls, respectively. Thus, the low serum levels were not due either to dilution in an increased plasma pool or to abnormal distribution among body compartments.
There was a marked increase in the IgG fractional catabolic rate (i.e. decreased half-life) in patients with intestinal lymphangiectasia with a mean of $33.9 \pm 17.7 \%$ of the intravascular pool catabolized per day as compared to $6.7 \pm 1.5 \%$ in normal control subjects. The IgG synthetic rates were normal or slightly elevated in the intestinal lymphangiectasia patients.

$\operatorname{IgM}$ and IgA turnover studies were done in three patients (Fig. 3, Table III). The results were comparable to those described above for IgG wherein the circulating and total body pools of the immunoglobulins were decreased in the patients with intestinal lymphangiectasia. Their mean total exchangeable $\operatorname{IgM}$ was $15.4 \mathrm{mg} / \mathrm{kg}$ as compared to $66 \mathrm{mg} / \mathrm{kg}$ in controls, and the mean total exchangeable $\operatorname{IgA}$ was $111 \mathrm{mg} / \mathrm{kg}$ as compared to $234 \mathrm{mg} / \mathrm{kg}$ in controls. The fractional catabolic rates were increased in the patients, whereas the rates of $\operatorname{IgM}$ and $\operatorname{Ig} \mathrm{A}$ synthesis were normal.

TABLE III

IgA and IgM metabolism in intestinal lymphangiectasia

\begin{tabular}{|c|c|c|c|c|c|c|c|c|}
\hline Patient & $\begin{array}{l}\text { Age, } \\
\text { sex }\end{array}$ & Serum level & $\begin{array}{c}\text { Total } \\
\text { circulating } \\
\text { IgA or IgM }\end{array}$ & $\begin{array}{l}\text { Total } \\
\text { exchangeable } \\
\text { IgA or IgM }\end{array}$ & $\begin{array}{c}\text { Intra- } \\
\text { vascular }\end{array}$ & $\underset{t}{\text { Survival }}$ & $\begin{array}{l}\text { Fractional } \\
\text { catabolic } \\
\text { rate }\end{array}$ & $\begin{array}{c}\text { Synthetic } \\
\text { rate }\end{array}$ \\
\hline \multicolumn{9}{|c|}{$\%$ IV pool/day } \\
\hline $\begin{array}{l}\text { L. H. } \\
\text { I. S. } \\
\text { J. T. }\end{array}$ & $\begin{array}{l}28 \mathrm{~F} \\
70 \mathrm{~F} \\
45 \mathrm{M}\end{array}$ & $\begin{array}{l}0.69 \\
1.24 \\
1.07\end{array}$ & $\begin{array}{l}26.8 \\
44.6 \\
42.6\end{array}$ & $\begin{array}{r}84.2 \\
152.7 \\
95.7\end{array}$ & $\begin{array}{l}31.8 \\
29.2 \\
44.5\end{array}$ & $\begin{array}{l}3.4 \\
5.0 \\
2.4\end{array}$ & $\begin{array}{l}64.2 \\
47.6 \\
65.0\end{array}$ & $\begin{array}{l}17.2 \\
21.1 \\
27.7\end{array}$ \\
\hline \multicolumn{2}{|c|}{$\begin{array}{l}\text { Patient mean } \\
\text { Controls (10) }\end{array}$} & $\begin{array}{c}1.00 \\
2.53 \pm 1.1\end{array}$ & $\begin{array}{c}38.0 \\
97 \pm 52\end{array}$ & $\begin{array}{c}110.9 \\
234 \pm 135\end{array}$ & $\begin{array}{c}35.2 \\
42.1 \pm 8.6\end{array}$ & $\begin{array}{c}3.6 \\
6.7 \pm 2.3\end{array}$ & $\begin{array}{c}58.9 \\
28.3 \pm 6.3\end{array}$ & $\begin{array}{c}22.0 \\
25 \pm 15\end{array}$ \\
\hline \multicolumn{9}{|l|}{$I g M$} \\
\hline $\begin{array}{l}\text { L. H. } \\
\text { N. B. } \\
\text { J. T. }\end{array}$ & $\begin{array}{l}28 \mathrm{~F} \\
40 \mathrm{M} \\
45 \mathrm{M}\end{array}$ & $\begin{array}{l}0.27 \\
0.32 \\
0.62\end{array}$ & $\begin{array}{r}9.8 \\
7.7 \\
17.7\end{array}$ & $\begin{array}{r}10.4 \\
9.9 \\
25.9\end{array}$ & $\begin{array}{l}94 \\
78 \\
68\end{array}$ & $\begin{array}{l}1.0 \\
1.5 \\
1.5\end{array}$ & $\begin{array}{r}73.3 \\
66.0 \\
60.0\end{array}$ & $\begin{array}{r}7.2 \\
4.6 \\
12.0\end{array}$ \\
\hline \multicolumn{2}{|c|}{$\begin{array}{l}\text { Patient mean } \\
\text { Controls }(10)\end{array}$} & $\begin{array}{c}0.40 \\
1.45 \pm 0.63\end{array}$ & $\begin{array}{c}11.7 \\
50 \pm 25\end{array}$ & $\begin{array}{c}15.4 \\
66 \pm 40\end{array}$ & $\begin{array}{l}80 \\
76 \pm 12\end{array}$ & $\begin{array}{c}1.3 \\
5.4 \\
\pm 1.0\end{array}$ & $\begin{array}{c}66.4 \\
17 \pm 4.0\end{array}$ & $\begin{array}{c}7.9 \\
8.9 \pm 6.2\end{array}$ \\
\hline
\end{tabular}


The mean fractional catabolic rates of $\operatorname{IgM}$ were $66.4 \%$ of the intravascular pool as compared to $17 \%$ in controls. Fractional catabolic rates of IgA averaged $58.9 \%$ in the patients as compared to $28.3 \%$ in controls. It is clear, therefore, that the reduced serum concentrations of $\operatorname{IgG}, \operatorname{IgA}$, and IgM in patients with intestinal lymphangiectasia were secondary to shortened survival of these proteins.

Antibody stimulation studies. Five patients and 14 controls were challenged with $\mathrm{Vi}$ and tularemia antigens. Hemagglutination titers at 2 wk were determined and are plotted in Fig. 4. The patients with intestinal lymphangiectasia were able to produce humoral antibody, although the anti-Vi titers were somewhat lower than those of the control group. Statistical analysis of these data on the basis of rank order testing indicates that the difference in titers is significant at the $5 \%$ confidence level for the $\mathrm{Vi}$ antigen, but not for the tularemia antigen. Thus, patients with intestinal lymphangiectasia are capable of humoral antibody responses, but peak titers may not be as high as in a control group.

Lymphocyte levels. Peripheral lymphocyte counts in patients with intestinal lymphangiectasia were compared with an age-matched control group (Fig. 5). The mean lymphocyte count of 42 normal individuals was $2500 \pm 600 / \mathrm{mm}^{3}$, whereas that of the 18 intestinal lymphangiectasia patients was $710 \pm 340 / \mathrm{mm}^{3}$. These differences are statistically significant $(P<0.001)$.

To gain insight into the cause of the lymphocytopenia, we determined the lymphocyte levels of patients with other forms of protein-losing gastroenteropathy. Low lymphocyte levels were found in patients with protein-losing gastroenteropathy associated with Whipple's disease, constrictive pericarditis, and regional enteritis (Fig. 5). Normal levels were found in patients with protein-losing gastroenteropathies associated with sprue, allergic enteropathy, and hypogammaglobulinemia. Interestingly, the intestinal lymphatics in each of the lymphocytopenic gastroenteropathies can be dilated just as in intestinal lymphangiectasia, but nonlymphocytopenic gastroenteropathies are not associated with this histological finding. This suggests that the occurrence of lymphocytopenia is secondary to structural lymphatic abnormalities of the gastrointestinal tract.
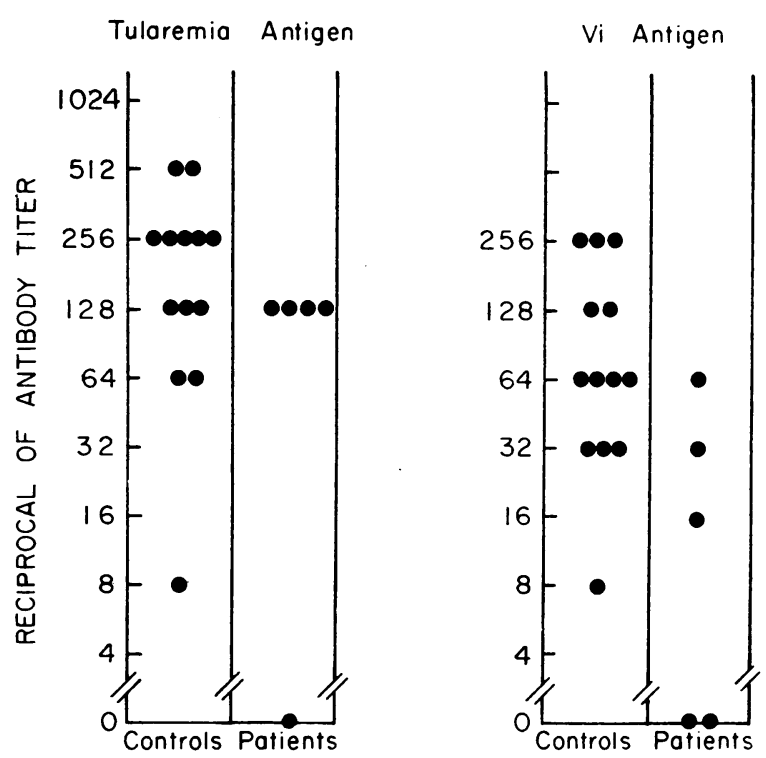

Fig. 4. Antibody Responses at 2 WK After IMMUNIZATION IN PATIENTS WITH INTESTINAL LYMPHANGIECTASIA AND CONTROL SUBJECTS.

Evaluation of the cellular hypersensitivity_skin tests. We performed intradermal skin tests on 12 patients using delayed hypersensitivity antigens (Fig. 6). $41 \%$ of the normal control group gave a positive response to intradermal second strength $\mathrm{PPD}$ in contrast to 0 of 12 intestinal lymphangiectasia patients. Similarly, $59 \%$ and $29 \%$ of the normal individuals gave a positive response to mumps and Trichophyton antigens, respectively; in all cases, intestinal lymphangiectasia patients tested with these antigens gave negative responses. In the case of Candida albicans antigen, 8 of 21 normals were positive as compared to 2 of 8 patients with intestinal lymphangiectasia. One of the two patients with intestinal lymphangiectasia that had a positive response had the highest lymphocyte level of the group, 1400 lymphocytes $/ \mathrm{mm}^{3}$. In total, $91 \%$ of the normal individuals had a positive response to at least one skin antigen, as compared to $17 \%$ of patients with intestinal lymphangiectasia.

DNCB skin tests performed on three patients were negative. $90 \%$ of normal individuals gave positive responses to this test as it was performed here (19).

Evaluation of cellular immunity-skin grafts. Sets of three skin grafts, consisting of $8 \mathrm{~mm}$ punch biopsy, full thickness skin sections, were trans- 


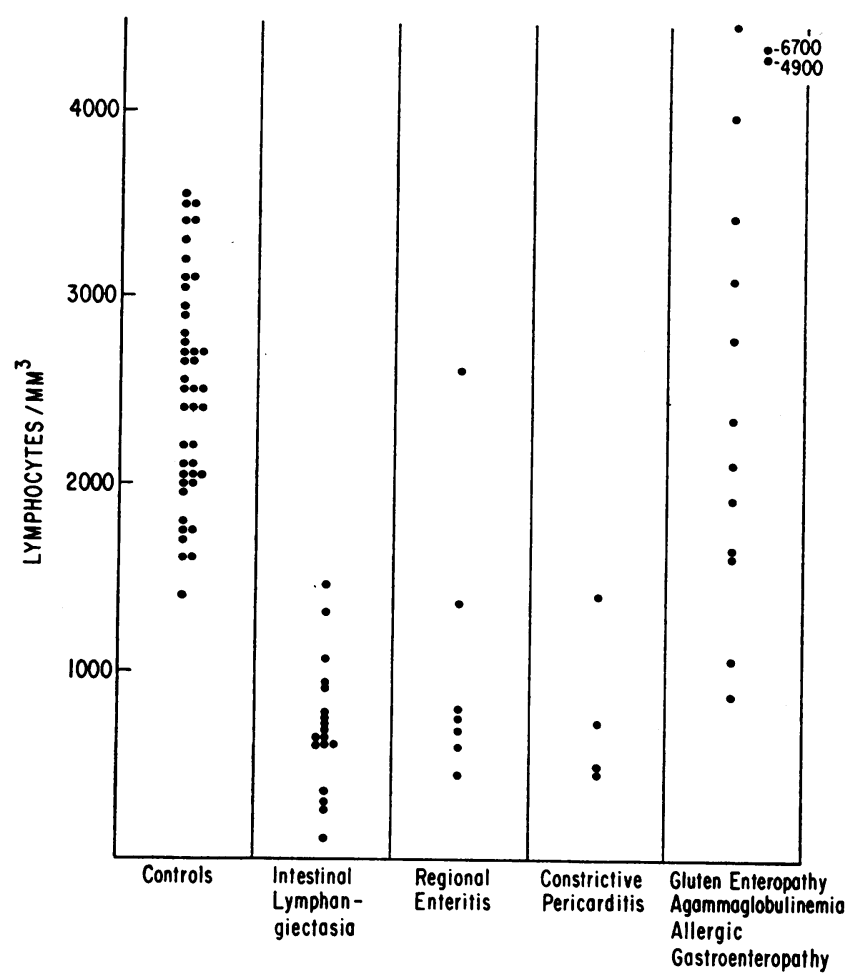

Fig. 5. Blood lymphocyte levels in patients With inTESTINAL LYMPHANGIECTASIA, CONTROL SUBJECTS, AND PATIENTS WITH OTHER FORMS OF PROTEIN-LOSING ENTEROPATHY. Lymphocytopenia is found in intestinal lymphangiectasia, regional enteritis, and constrictive pericarditis. Normal lymphocyte levels are found in gluten enteropathy, agammaglobulinemia with protein-losing gastroenteropathy, and in allergic gastroenteropathy.

planted to the medial arm surface in four patients of rejection during the 1-2 yr period in which they with intestinal lymphangiectasia. In each case, have been observed. In two of the four cases, a the transplanted grafts have shown no evidence second graft from the original donor was trans-

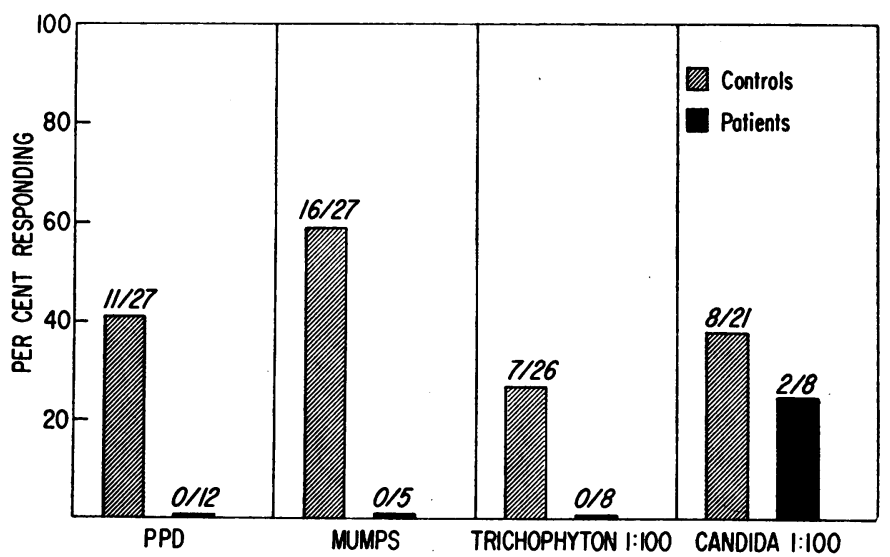

Fig. 6. Skin test RESPONSES IN PATIENTS With INTESTINAL LYMPHANGIECTASIA AND CONTROL SUBJECTS. 
TABLE IV

Immunologic disorders

\begin{tabular}{|c|c|c|c|c|c|c|c|c|c|}
\hline \multirow[b]{2}{*}{ Patient } & \multicolumn{3}{|c|}{ Immunoglobulin } & \multirow{2}{*}{$\begin{array}{c}\text { Mean } \\
\text { lymphocyte } \\
\text { level }\end{array}$} & \multicolumn{2}{|c|}{$\begin{array}{l}2-w k \\
\text { antibody titer }\end{array}$} & \multicolumn{2}{|c|}{ Skin test response } & \multirow[b]{2}{*}{$\underset{\text { response }}{\text { Homograft }}$} \\
\hline & IgG & IgM & IgA & & $\mathrm{Vi}$ & Tularemia & $\begin{array}{c}\text { Skin } \\
\text { antigens (4) }\end{array}$ & $\mathrm{DNCB}$ & \\
\hline & & $m g / m$ & & cells $/ m m$ & & & & & \\
\hline N. B. & 5.0 & 0.32 & 1.4 & 770 & 64 & 128 & Negative & - & - \\
\hline B. C. & 3.2 & 0.92 & 1.1 & 1315 & 32 & 128 & Negative & Negative & No rejection \\
\hline L. H. & 1.1 & 0.27 & 0.69 & 670 & 0 & 128 & Negative & ivegative & observed after \\
\hline I. S. & 6.5 & 1.0 & 1.2 & 750 & 16 & 128 & Negative & Negative & prolonged \\
\hline J. T.* & 4.0 & 0.62 & 1.1 & 620 & 0 & 0 & Negative & Negative & observation \\
\hline
\end{tabular}

DNCB, dinitrochlorobenzene.

* Patient J. T. did respond to diphtheria, tetanus, and blood group substance antigens.

planted. There has been no evidence of rejection after 6 and 12 months. The survival of the transplanted tissue was judged by the persistence of pigmentation differences between donor and recipient, the persistence of small skin tattoos placed in the dermis of the graft, and the absence of the inflammation usually associated with rejection. In two instances, one of the grafts was removed and examined histologically, the grafts contained normal-appearing skin without lymphocytic infiltration.

Clinical evaluation of patients with intestinal lymphangiectasia. The case records of 18 patients with intestinal lymphangiectasia were carefully reviewed for incidence of infection. Two of the six patients under $10 \mathrm{yr}$ of age died at 7 and $9 \mathrm{yr}$ after prolonged periods of severe debilitation; during these periods infections were frequent. One of the patients had furunculosis, cellulitis of the abdominal wall, and terminal (A. aerogenes) peritonitis. The other patient had three episodes of furunculosis, one episode of pneumonitis, one episode of otitis media, and one urinary tract infection. The other four patients under $10 \mathrm{yr}$ of age did not have an increased incidence of infection. In the older age group (over $16 \mathrm{yr}$ of age) only two of the 12 patients studied have had more infections than one might expect. These infections were predominantly respiratory and never required hospitalization. None of the 18 patients had significant fungal infection or tuberculosis. Thus, infection has been marked in only two of the 18 patients with intestinal lymphangiectasis, despite the fact that the patients had significant disorders of delayed hypersensitivity.

\section{Discussion}

The patients with intestinal lymphangiectasia had reduced serum concentrations of each class of immunoglobulin, but were able to synthesize antibodies to antigenic challenge in a nearly normal fashion. They had lymphocytopenia, skin anergy, and a striking failure to reject skin homografts (Table IV). These diverse immunologic disorders may be due to a primary disorder of intestinal lymphatics with chronic loss of both immunoglobulins and lymphocytes into the gastrointestinal tract.

The reductions in immunoglobulin concentration were associated with normal synthetic rates and increased fractional catabolic rates (i.e. shortened immunoglobulin survivals). The increased fractional catabolic rates were presumably due to excessive loss of immunoglobulins into the gastrointestinal tract since these patients with intestinal lymphangiectasia were shown with albumin- ${ }^{51} \mathrm{Cr}$ and ceruloplasmin- ${ }^{67} \mathrm{Cu}$ to lose from 5 to $50 \%$ of their intravenous protein pool into the gastroinestinal tract daily as compared with $0.5-2.0 \%$ in control subjects $(20,21)$. In spite of the reduced serum immunoglobulin levels, synthetic rates were not compensatorily increased. Thus, in these studies as well as in others $(22,23)$, synthetic rates of immunoglobulins do not appear to be stimulated by low immunoglobulin concentrations.

The excess catabolism, i.e. the fraction of the intravascular pool catabolized per day above normal, was of the same order of magnitude for all three immunoglobulins. This is most consistent with the concept that serum or a fluid closely related to serum, such as lymph, was lost in bulk 
fashion into the gastrointestinal tract without relation in the molecular size of the proteins. The pattern of plasma protein loss in intestinal lymphangiectasia is in contrast to that seen in the nephrotic syndrome in which a selective loss of proteins into the urine occurs based on the sieving property of the glomerular basement membrane (23). In nephrosis, the excess fractional catabolism for various proteins is unequal and that of $\mathrm{IgG}$ is markedly greater than that of $\operatorname{IgM} .^{9}$

Patients with intestinal lymphangiectasia and nephrosis illustrate that the concentration of the serum proteins, including the immunoglobulins, can be decreased because of shortened protein survival. This is in contrast to the more widely known immunoglobulin deficency states in which synthetic defects are the major lesion $(1,10)$. In these cases, however, excessive loss of protein through the gastrointestinal tract may develop secondarily without associated intestinal lymphatic abnormalities (22). Myotonic dystrophy is another example of an immunoglobulin deficiency state due to shortened protein survival; here the lesion is increased endogenous catabolism specific for IgG, and no excessive loss occurs (24).

The difference between hyposynthetic hypogammaglobulinemias and hypogammaglobulinemias due to shortened protein survival is reflected in the response to antigenic challenge. Patients with hyposynthetic hypogammaglobulinemia have markedly impaired ability to make antibodies (1), whereas patients with intestinal lymphangiectasia have very considerable antibody responses which indicate normal immunoglobulin synthetic mechanisms. The observation that titers achieved may be lower than those of normal controls could be due in part to the more rapid rate of catabolism of synthesized antibodies or, as discussed below, they may be lower because of the lymphocytopenia.

Moderate-to-marked lymphocytopenia was seen in the patients with intestinal lymphangiectasia. In addition, a number of the patients also had a reduction in the number of lymphocytes present in the submucosa of the appendix and in lymph nodes. Several related observations suggest that the lymphocytopenia noted in patients with intestinal lymphangiectasia is due to loss of lymphocytes into the gastrointestinal tract. (a) All the

\footnotetext{
${ }^{9}$ Strober, W., G. Cohen, and T. A. Waldmann. Unpublished observations.
}

gastroenteropathies associated with lymphocytopenia (Whipple's disease, regional enteritis, and constrictive pericarditis) have histologically demonstrable intestinal lymphatic abnormalities with dilated intestinal lymphatics or evidence of intestinal lymphatic obstruction (25-27). The nonlymphocytopenic protein-losing gastroenteropathies are not associated with intestinal lymphatic abnormalities (28-30). (b) In the lymphocytopenic gastroenteropathies that are reversible, the lymphocytopenia is also reversible; thus, there was a remission of the hypoproteinemia and lymphocytopenia in patients with constrictive pericarditis ${ }^{10}$ (31), Whipple's disease (26), or intestinal lymphangiectasia after appropriate medical or surgical therapy. (c) Finally, and most significantly, lymphatic fluid has been shown to leak directly into the bowel lumen in some patients with intestinal lymphangiectasia, i.e. chyle has been aspirated directly from the duodenum in some cases $(32,33)$, and radiopaque lymphangiogram dye entered the bowel lumen after injection into the lymphatics of the foot in other cases $(32,34)$. All these facts suggest that lymphocyte-rich lymph fluid is lost into the gastrointestinal tract, and this, in turn, results from the underlying intestinal lymphatic abnormality. Thus, the same mechanism implicated in the loss of immunoglobulins would seem to be the basis of the lymphocytopenia.

The most striking immunological defects in patients with intestinal lymphangiectasia are the decreased delayed skin reactivity to certain antigens and the long-term acceptance of skin homografts. These phenomena are best explained by the observed lymphocyte depletion, since the lymphocyte has been shown to play a major role in delayed hypersensitivity. In this connection, delayed hypersensitivity (including homograft sensitivity) may be transferred with lymphoid cells (35-37), but not with serum, even if serum contains high concentrations of cytotoxic antibody $(38,39)$. In addition, homografts placed in cell-impermeable chambers are generally not destroyed in recipients even if the recipient has been sensitized to the homograft previously. Since humoral factors,

\footnotetext{
10 Strober, W., L. S. Cohen, T. A. Waldmann, and E. Braunwald. Tricuspid regurgitation, a newly recognized cause of protein-losing enteropathy, lymphocytopenia, and immunologic deficiency. Am. J. Med. In press.
} 
but not cells, may freely enter the chamber, these experiments show that direct cellular contact of sensitized lymphoid tissue and foreign cells are necessary for rejection $(40,41)$.

The importance of lymphocytes in delayed hypersensitivity is also demonstrable in experimentally induced lymphocytopenia. Thus, anergy and lymphocytopenia are associated in certain rodents after neonatal thymectomy $(42,43)$, in animals receiving antilymphocyte antisera (44), in patients with Swiss-type agammaglobulinemia $(45,46)$, and in animals and man after artificial thoracic duct drainage $(47,48)$.

Of the various lymphocyte depletion states, patients with intestinal lymphangiectasia appear to be most analogous to animals with artificial thoracic duct drainage. In both conditions, lymphocytopenia, hypogammaglobulinemia, and severe impairment of homograft immunity are evident (47-49). However, patients with intestinal lymphangiectasia may have normal antibody responses, whereas animals and man with artificial thoracic duct drainage have profound depression in antibody production to primary antigenic challenge $(48,49)$. The difference may be that lymph drainage is more complete and the lymphocytopenia more marked in the artificial drainage experiments than in the patients, or it may be related to the different doses and types of stimulating antigens used in the studies. Thus, patients with intestinal lymphangiectasia may retain enough lymphocytes to form antibodies, but not enough to mount a graft rejection phenomenon. The ability to produce some antibodies to certain antigens is retained in lymphocytopenic and anergic states other than intestinal lymphangiectasia, such as the thymectomized rodent (50), animals receiving antilymphocyte antisera (51), and patients with certain immunologic deficiency diseases (52).

Although the lymphocytopenia seen in intestinal lymphangiectasia would appear to be an adequate explanation for the anergy observed, alternative or concomitant explanations may be considered. One such explanation is that the immune defect is secondary to an intrinsic abnormality of the lymphocyte itself. In this case, the impaired cellular response seen in intestinal lymphangiectasia would be more analogous to that of Hodgkin's disease, in which decreased delayed skin responses, and defective in vitro lymphocyte transformation, as well as lymphocytopenia, have been observed $(2,3)$. Studies of in vitro lymphocyte function of patients with intestinal lymphangiectasia are currently under investigation.

A second explanation for the observed anergy is that the loss of the essential humoral factors, rather than lymphocytes, is the underlying immunologic defect in patients with intestinal lymphangiectasia. This possibility is contrary to the dominant view that delayed hypersensitivity is not mediated or transferred by a circulating humoral factor (38). Evidence to the contrary is provided by Najarian and Feldman (53) who showed that sensitized cells placed in cell-impermeable, intraperitoneal Millipore chambers had augmented ability to reject homografts; however, similar experiments by Billingham and coworkers (54) could not corroborate these results. In sum, it is reasonable to conclude that while loss of humoral factors may play a supportive or concomitant role in the production of anergy in intestinal lymphangiectasia, the loss of lymphocytes is a sufficient condition for the immunologic defect observed. It is of interest that patients with nonlymphocytopenic gastroenteropathies provide a clinical situation in which plasma proteins, but not lymphocytes, are lost into the gastrointestinal tract; this group of patients may be profitably studied for evidences of immune deficiency.

Clinical implications. Patients with protein-losing gastroenteropathy may be classified into lymphocytopenic and nonlymphocytopenic categories. This fact may be useful in the differential diagnosis of gastrointestinal protein loss and in determining the therapy to be used. As to diagnosis, lymphocytopenia is usually not seen in patients with gastrointestinal protein loss secondary to inflammation or ulceration of the gastrointestinal mucosa, as in carcinoma of the bowel or ulcerative colitis. In addition, it is not seen in patients with gastrointestinal allergy or with biochemical defects in the mucosal cells, as in allergic gastroenteropathy or gluten-induced enteropathy. Lymphocytopenia may be expected in patients with disorders of small intestinal lymphatics: intestinal lympangiectasia, cardiac gastroenteropathies, or Whipple's disease. The rate of gastrointestinal protein loss is significantly reduced and lymphocyte level returns toward normal in some of the 
patients in this latter group when appropriate therapy is instituted. This is seen dramatically in constrictive pericarditis after pericardiectomy, as well as in tricuspid regurgitation after medical recompensation of cardiac failure. ${ }^{10}$ In addition, several patients with intestinal lymphangiectasia have obtained elevations of serum protein levels $(55,56)$ as well as lymphocyte counts ${ }^{11}$ when on a very low fat or middle chain triglyceride diet.

In view of the skin anergy seen in lymphocytopenic patients, one cannot use delayed hypersensitivity skin tests to rule out tuberculosis or fungal disease. This is well illustrated in patients with constrictive pericarditis, protein-losing enteropathy, and lymphocytopenia, for which a negative skin test may erroneously be used to eliminate the possibility of tuberculosis. We have seen one such case in which surgical cure of the pericardial lesion led to a return to normal of the lymphocyte count and a conversion of a negative to positive tuberculin skin test.

Adults with intestinal lymphangiectasia have profound anergy, yet have few serious infections, in contrast to subjects with Swiss-type agammaglobulinemia $(44,45)$. In addition, patients with intestinal lympangiectasia have no increased incidence of fungal disease in contrast to subjects with Hodgkin's lymphoma (1). That patients with intestinal lymphangiectasia are generally quite healthy, yet have profound anergy, suggests that the production of an internal fistula between the thoracic duct and the gastrointestinal, biliary, or urinary tract might be a valuable adjunct in the production of anergy required for successful organ transplantation in man.

\section{Acknowledgments}

We wish to thank Dr. Donald Waldorf for aid in performing several of the skin grafts and Miss Delores Houston for technical assistance.

\section{References}

1. Good, R. A., W. D. Kelly, J. Rötstein, and R. L. Varco. 1962. Immunological deficiency diseases. Agammaglobulinemia, hypogammaglobulinemia, Hodgkin's disease, and sarcoidosis. Progr. Allergy. 6: 187.

2. Kelly, W. D., D. L. Lamb, R. L. Varco, and R. A. Good. 1960. An investigation of Hodgkin's dis-

11 Waldmann, T. A. and W. Strober. Unpublished observations. ease with respect to the problem of homotransplantation. Ann. N. Y. Acad. Sci. $87: 187$.

3. Aisenberg, A. C., and S. Leskowitz. 1963. Antibody formation in Hodgkin's disease. New Engl. J. Med. 268: 1269.

4. Waldmann, T. A. Protein-losing enteropathy. 1966. Gastroenterology. 50: 422.

5. Gordon, R. S., Jr. 1959. Exudative enteropathy: abnormal permeability of the gastrointestinal tract demonstrable with labelled polyvinylpyrrolidone. Lancet. 1: 325 .

6. Waldmann, T. A. 1961. Gastrointestinal protein loss demonstrated by ${ }^{51} \mathrm{Cr}$-labelled albumin. Lancet. 2: 121.

7. Mancini, G., J. P. Vaerman, A. O. Carbonara, and J. F. Heremans. 1964. A single-radial-diffusion method for the immunological quantitation of proteins. In Protides of the Biological Fluids. Proceedings of the 11 th Colloquium. H. Peeters, editor. Elsevier Publishing Co., Amsterdam. 370.

8. Fahey, J. L., and E. M. McKelvey. 1965. Quantitative determination of serum immunoglobulins in antibody-agar plates. J. Immunol. $94: 84$.

9. Fahey, J. L., P. F. McCoy, and M. Goulian. 1958. Chromatography of serum proteins in normal and pathologic sera: the distribution of protein-bound carbohydrate and cholesterol, siderophilin, thyroxin-binding protein, $B_{12}$-binding protein, alkaline and acid phosphatases, radioiodinated albumin and myeloma proteins. J. Clin. Invest. $37: 272$.

10. Barth, W. F., R. D. Wochner, T. A. Waldmann, and J. L. Fahey. 1964. Metabolism of human gamma macroglobulins. J. Clin. Invest. 43, 1036.

11. McFarlane, A. S. 1958. Efficient trace-labelling of proteins with iodine. Nature. 182: 53.

12. Berson, S. A., R. S. Yalow, S. S. Schreiber, and J. Post. 1953. Tracer experiments with $\mathrm{I}^{\text {191-labeled }}$ human serum albumin: distribution and degradation studies. J. Clin. Invest. $32: 746$.

13. Pearson, J. D., N. Veall, and H. Vetter. 1958. A practical method for plasma albumin turnover studies. Sonderbande Strahlentherapie. 38: 290.

14. Webster, M. E., M. Landy, and M. E. Freeman. 1952. Studies on Vi antigen. II. Purification of $\mathrm{Vi}$ antigen from E. coli 5396/38. J. Immunol. 69: 135.

15. Webster, M. E., J. F. Sagin, P. R. Anderson, S. S. Breese, M. E. Freeman, and M. Landy. 1954. Studies on Vi antigen. IV. Physico-chemical characterization of $\mathrm{Vi}$ antigens isolated from $\mathrm{V}$ form enterobacteriaceae. J. Immunol. 73 : 16.

16. Kadull, P. J., H. R. Reames, L. L. Coriell, and L. Foshay. 1950. Studies on tularemia. V. Immunization of man. J. Immunol. $65: 425$.

17. Landy, M., and E. Lamb. 1953. Estimation of Vi antibody employing erythrocytes treated with purified Vi antigen. Proc. Soc. Exptl. Biol. Med. 82 : 593.

18. Wright, G. G., and R. J. Feinberg. 1952. Hemagglutination by tularemia antisera: further observa- 
tions on agglutination of polysaccharide-treated erythrocytes and its inhibition by polysaccharide. J. Immunol. $68: 65$.

19. Kligman, A. M., and W. L. Epstein. 1959. Some factors affecting contact sensitization in man. In Mechanisms of Hypersensitivity. J. H. Shaffer, G. A. LoGrippo, and M. W. Chase, editors. Little, Brown and Company, Boston. 713.

20. Waldmann, T. A., and R. D. Wochner. 1964. The use of ${ }^{51} \mathrm{Cr}$-labelled albumin in the study of proteinlosing enteropathy. In Protides of the Biological Fluids. Proceedings of the 11th Colloquium. $\mathrm{H}$. Peeters, editor. Elsevier Publishing Co., Amsterdam. II : 224.

21. Waldmann, T. A., A. G. Morell, R. D. Wochner, W. Strober, and I. Sternlieb. 1967. Measurement of gastrointestinal protein loss using ceruloplasmin labeled with ${ }^{67}$ copper. J. Clin. Invest. 46: 10.

22. Waldmann, T. A., and P. J. Schwab. 1965. IgG (7s gamma globulin) metabolism in hypogammaglobulinemia: studies in patients with defective gamma globulin synthesis, gastrointestinal protein loss, or both. J. Clin. Invest. 44 : 1523.

23. Joachim, G. R., J. S. Cameron, M. Schwartz, and E. L. Becker. 1964. Selectivity of protein excretion in patients with the nephrotic syndrome. $J$. Clin. Invest. 43 : 2332.

24. Wochner, R. D., G. Drews, W. Strober, and T. A. Waldmann. 1966. Accelerated breakdown of immunoglobulin G ( $\operatorname{IgG}$ ) in myotonic dystrophy: a hereditary error of immunoglobulin catabolism. J. Clin. Invest. $45: 321$.

25. Petersen, V. P., and J. Hastrup. 1963. Proteinlosing enteropathy in constrictive pericarditis. Acta Med. Scand. 173: 401.

26. Laster, L., T. A. Waldmann, L. F. Fenster, and J. W. Singleton. 1966. Albumin metabolism in patients with Whipple's disease. J. Clin. Invest. 45 : 637.

27. Ammann, R. W. 1964. Pathogenesis and etiology of regional enteritis. In Gastroenterology. H. L. Bockus, editor. W. B. Saunders Co., Philadelphia. II : 242.

28. Waldmann, T. A., R. D. Wochner, L. Laster, and R. S. Gordon, Jr. 1967. Allergic gastroenteropathy. A cause of excessive gastrointestinal protein loss. New Engl. J. Med. 276: 761.

29. Huizenga, K. A., E. E. Wollaeger, P. A. Green, and B. F. McKenzie. 1961. Serum globulin deficiencies in non-tropical sprue, with report of two cases of acquired agammaglobulinemia. Am. J. Med. 31: 572.

30. Rubin, C. E., L. L. Brandborg, P. C. Phelps, and H. C. Taylor. 1960. Studies of coeliac disease. I. The apparent identical and specific nature of the duodenal and proximal jejunal lesion in coeliac disease and idiopathic sprue. Gastroenterology. 38 : 28.

31. Davidson, J. D., T. A. Waldmann, D. S. Goodman, and R. S. Gordon, Jr. 1961. Protein-losing gas- troenteropathy in congestive heart failure. Lancet. 1: 899.

32. Vesin, P., A. Roberti, V. Bismuth, J. P. DesprezCurely, G. Desbuquois, and R. Viguié. 1965. Protein and calcium-losing enteropathy with lymphatic fistula into the small intestine. In Physiology and Pathophysiology of Plasma Protein Metabolism. Hans Koblet, editor. Hans Huber, Berne. 179.

33. Stoelinga, G. B. A., P. J. J. Van Munster, and J. P. Slooff. 1963. Chylous effusions into the intestine in a patient with protein-losing gastroenteropathy. Pediatrics. 31 : 1011.

34. Mistilis, S. P., A. P. Skyring, and D. D. Stephen. 1965. Intestinal lymphangiectasia: mechanism of enteric loss of plasma-protein and fat. Lancet. 1 : 77.

35. Mitchison, N. A. 1955. Studies on the immunological response to foreign tumor transplants in the mouse. I. The role of lymph node cells in conferring immunity by adoptive transfer. J. Exptl. Med. $102: 157$.

36. Billingham, R. E., L. Brent, and P. B. Medawar. 1954. Quantitative studies on tissue transplantation immunity. II. The origin, strength, and duration of actively and adoptively acquired immunity. Proc. Roy. Soc. Ser. B. 143: 58.

37. Wesslén, T. 1952. Passive transfer of tuberculin hypersensitivity by viable lymphocytes from the thoracic duct. Acta Tuberc. Scand. 26: 38.

38. Billingham, R. E., and L. Brent. 1956. Further attempts to transfer transplantation immunity by means of serum. Brit. J. Exptl. Pathol. 37: 566.

39. Mitchison, N. A., and O. L. Dube. 1955. Studies on the immunological response to foreign tumor transplants in the mouse. II. The relation between hemagglutinating antibody and graft resistance in the normal mouse and mice pretreated with tissue preparations. J. Exptl. Med. 102: 179.

40. Weaver, J. M., G. H. Algire, and R. T. Prehn. 1955. The growth of cells in vivo in diffusion chambers. II. The role of cells in the destruction of homografts in mice. J. Natl. Cancer Inst. 15: 1737.

41. Fujimoto, Y., T. Hasegawa, C. G. Watson, and J. R. Brooks. 1966. The role of lymphoid cells in homograft rejection: Circulating and cellular aspects. Transplant. Bull. 4 : 668.

42. Miller, J. F. A. P., A. H. E. Marshall, and R. G. White. 1962. The immunological significance of the thymus. Advan. Immunol. 2 : 111.

43. Good, R. A., A. P. Dalmasso, C. Martinez, O. K. Archer, J. C. Pierce, and B. W. Papermaster. 1962. The role of the thymus in the development of immunologic capacity in rabbits and mice. $J$. Exptl. Med. 116: 773.

44. Waksman, B. H., S. Arbouys, and B. G. Arnason. 1961. The use of specific "lymphocyte" antisera 
to inhibit hypersensitive reaction of the "delayed" type. J. Exptl. Med. 114: 997.

45. Hitzig, W. H., Z. Biró, H. Bosch, and H. J. Huser. 1958. Agammaglobulinämie und alymphocytose mit schwund des lympatischen gewebes. Helv. Paediat. Acta 13: 551.

46. Rosen, F. S., D. Gitlin, and C. A. Janeway. 1962. Alymphocytosis, agammaglobulinemia, homografts, and delayed hypersensitivity: study of a case. Lancet. 2: 380.

47. McGregor, D. D., and J. L. Gowans. 1964. Survival of homografts of skin in rats depleted of lymphocytes by chronic drainage from the thoracic duct. Lancet. 1: 629.

48. Irvin, G. L., III, W. S. Tunner, and P. P. Carbone. 1965. Effect of thoracic duct lymph drainage on the immune response in man. Clin. Res. 13: 288.

49. McGregor, D. D., and J. L. Gowans. 1963. The antibody responses of rats depleted of lymphocytes by chronic drainage from the thoracic duct. $J$. Exptl. Med. $117: 303$.

50. Defendi, V., R. A. Roosa, and H. Koprowski. 1964. Effect of thymectomy at birth on response to tissue, cells and virus antigens. In The Thymus in Immunobiology. R. A. Good and A. E. Gabrielsen, editors. Hoeber-Harper, New York. 504.
51. Monaco, A. P., M. L. Wood, and P. S. Russell. 1965. Adult thymectomy : effect on recovery from immunologic depression in mice. Science. 149: 432.

52. Nezelof, C., M.-L. Jammet, P. Lortholary, B. Labrune, and M. Lamy. 1964. L'hypoplasie heréditaire du thymus: sa place et sa responsabilité dans une observation d'aplasie lymphocytaire, normoplasmocytaire et normoglobulinémique du nourrisson. Arch. Franc. Pediat. 21 : 897.

53. Najarian, J. S., and J. D. Feldman. 1962. Passive transfer of transplantation immunity. I. Tritiated lymphoid cells. II. Lymphoid cells in millipore chambers. J. Exptl. Med. 115: 1083.

54. Billingham, R. E., W. K. Silvers, and D. B. Wilson. 1963. Further studies on adoptive transfer of sensitivity to skin homografts. J. Exptl. Med. 118: 397 .

55. Jeffries, G. H., A. Chapman, and M. H. Sleisenger. 1964. Low-fat diet in intestinal lymphangiectasia : its effect on albumin metabolism. New Engl. J. Med. 270: 761.

56. Holt, P. 1964. Dietary treatment of protein loss in intestinal lymphangiectasia. The effect of eliminating dietary long chain triglycerides on albumin metabolism in this condition. Pediatrics. $34: 629$. 